\section{DIARY}

An introduction to the

Kois Curriculum

Date: 5 October 2012

Venue: Queensway Education Centre

Billingham

Telephone: 01642554667

www.queensway.co.uk

Surgical and Prosthetic Solutions with Nobel Active

Date: 10 October 2012

Venue: Queensway Education Centre,

Billingham

Telephone: 01642554667

www.queensway.co.uk

Oral-B Up To Date seminars

Date and venue:

11 October 2012,

Radisson Blu Hotel, Manchester

8 November 2012,

Novotel St Pancras, London

22 November 2012, National

Motorcycle Museum, Birmingham

29 November 2012

Celtic Manor, Newport

Telephone: 07585508550

Email: julia@ab-communications.com

BDA Seminar: Clinical Expert

Series Lecture: No post no

crown dentistry

Date: 26 October 2012

Venue: BDA, London

Telephone: 02075634590

Email: events@bda.org

www.bda.org/events

Bruxism Awareness Week

Date: 22-28 October 2012

www.s4sdental.com/

BDTA Dental Showcase

Date: 4-6 October 2012

Venue: ExCeL London

www.dentalshowcase.com

\section{JAN-ERIK AHLBERG}

It is with much sadness that we report the death on 10 August 2012 of Dr Jan-Erik Ahlberg, who was the Executive Director of the FDI from 1975-1990 when the Federation was headquartered on the third floor of the British Dental Association (BDA) building in London.

\title{
CHILE CREATES CAVITY KILLER
}

A new molecule has been created by researchers in Chile that could make teeth 'cavity proof', killing the bacteria known to cause caries in less than 60 seconds.

Named 'Keep 32' after the number of teeth in the mouth, researchers Jose Cordova and Erich Astudillo hope the product could be used in toothpastes, mouthwashes, floss and even food. Chemical trials have shown that the cavity-causing bacteria Streptococcus mutans can be eliminated for hours with the molecule.

Procter \& Gamble and five other chemical giants are fighting for the patent to Keep 32, with the hope that successful human trials could see products using the molecule on the market in just over a year. If Keep 32 is classed as an antibiotic then proof of limited health consequences would be required before it could be used in a variety of processes.

Despite the interest in the molecule, some argue that oral disease prevention should focus on balancing the bacterial biofilms already in the mouth rather than targeting and removing specific 'harmful' bacteria. A recent review from Philip Marsh published in the British Dental Journal ${ }^{1}$ stressed the importance of the relationship between humans and their natural microflora and the risk of dental disease associated with an imbalance of resident bacteria. Marsh pointed out that 'it is too simplistic to talk of the presence of "good” or "bad” bacteria'.

1. Marsh P D. Contemporary perspective on plaque control. Br Dent J 2012; 212: 601-606

By Laura Pacey

\section{'PAIN FREE' PRACTICE LAUNCHED}

A spa-style dental practice offering 'pain free dentistry' has been officially opened in Colchester.

Dentist Direct's first practice allows patients to be treated with revolutionary laser technology which can be used instead of drills and needles for almost any dental procedure and which - in most cases - is completely painless.

The technology, Waterlase iPlus, works by fusing laser energy with a gentle stream of water, reducing pain, anxiety and trauma for patients and creating a much more comfortable experience for them.

Dentist Direct offers dentists a new route into business through a joint venture dental franchise (JVDF) opportunity, allowing dentists to run their own practice while receiving support from the Head Office for non-clinical functions.

Principal dentist at the new practice, Dr Neel Sanghavi (pictured fourth from right), said that he was very excited to be heading up Dentist Direct Colchester.

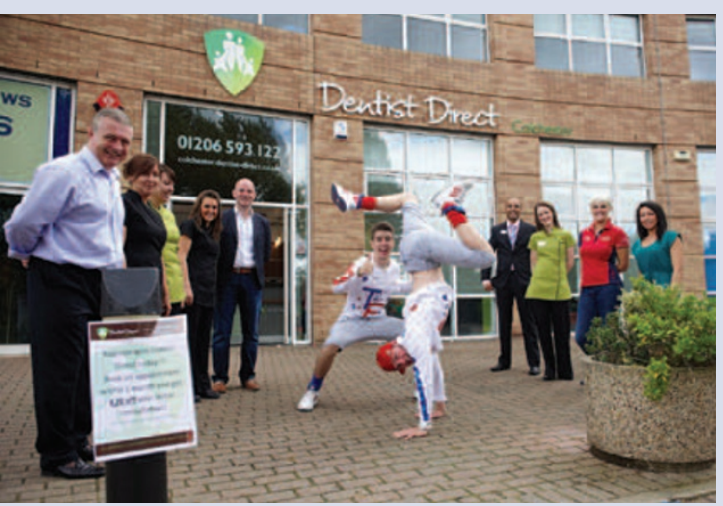

BDA BULLETIN

- The BDA has welcomed a Department of Health proposal that providers of primary denta services in England will not be subject to licensing by Monitor. The proposal follows extensive lobbying by the BDA.

- The BDA has pressed the argument for a properly funded NHS dental service in Scotland, pointing out that a smaller slice of the 'financial cake' for dentistry is not a viable option. Recently the BDA has actively engaged with the Scottish Government and made considerable representations over the issue of protecting the General Dental Practice Allowance.

- The BDA says that the report Dental Earnings and Expenses, England and Wales, 2010/11, published by the NHS Information Centre in August, shows a fall in dentists' average taxable income for the second year running, while the costs of providing premises, equipment, staff and materials essential to patient care have spiralled upwards. The average taxable income for all self-employed primary care dentists in England and Wales in 2010/11 was $€ 77,900$, a $13 \%$ pay cut over two years. 